\title{
The role of individual terrain units in the water balance of wetland tundra
}

\author{
L. Dale Boudreau, Wayne R. Rouse \\ Department of Geography, McMaster University, Hamilton, Ontario, Canada L8S 4K1
}

\begin{abstract}
The water balance of a High Subarctic wetland was measured in a newly established research basin near Churchill, Manitoba, Canada. Measurements spanned the growing season from early June through to the end of August 1991. The watershed was instrumented such that the water budget could be monitored over each of the dominant terrain units. The study basin has 5 major terrain types consisting of sedge-dominated wetland, upland lichen-heath, tundra lakes and ponds, willowbirch wetland, and open spruce forest, in decreasing order of coverage. These terrain units, and the ecosystem as a whole, are representative of coastal wetlands underlain by permafrost in the Hudson Bay Lowland. Runoff and thus streamflow were closely tied to the moisture status of the peatlands and to the depth of the active layer. During 2 unusually dry periods, the peatlands remained wet, which indicates a lack of water mobility when the water table drops below the surface of the wetland. Streamflow response to rainfall during these periods was small in comparison to early summer when the frost table was near the surface, or to wet periods when the water table rose above the surface. Energy balance measurements showed the lakes and ponds to have about $15 \%$ higher net radiation than wetlands and $29 \%$ greater than upland lichen-heath. From 9 to $18 \%$ of net radiation was used in thawing and heating the ground whereas the latent heat flux for the various terrain types utilized from 49 to $83 \%$ of net radiation. Even with unusually large rainfalls that occurred in July, evaporation exceeded precipitation over the course of the summer. Despite this, runoff was high and required a large negative change in groundwater storage to account for it. The lichen-heath and ponds exhibited the greatest change in water storage. The drainage of water from the uplands to the lowlands maintained the soil moisture of the peatlands and contributed to streamflow. Each terrain type had a characteristic water balance due to differences in one or more of the hydrologic variables (evapotranspiration, runoff and storage). This has important implications concerning the impact on the water balance of a change in surface cover brought about by a change in climate.
\end{abstract}

KEY WORDS: Water balance Energy balance $\cdot$ Wetlands $\cdot$ Evaporation

\section{INTRODUCTION}

A water balance that quantifies the inputs and outputs of water within a system is particularly useful for a wetland since the whole ecosystem depends on the collection, storage, uptake, runoff and evaporation of water. The National Wetlands Working Group (NWWG 1987) defines a wetland as land that is saturated with water long enough to promote wetland or aquatic processes as indicated by poorly drained soils, hydrophytic vegetation, and various kinds of biological activity which are adapted to a wet environment. Wetlands cover approximately $18 \%$ of Canada's land surface (Zoltai \& Pollett 1983) and represent a large carbon reservoir. The Hudson Bay Lowland comprises the largest contiguous wetland in North America. General circulation models suggest that these wetlands are very susceptible to climate change (Roots 1989, Rouse 1991, Rizzo \& Wiken 1992). In the event of 'greenhouse warming', the potential exists for peatlands to release large amounts of carbon dioxide (Moore 1986), an efficient greenhouse gas. Enhanced carbon dioxide release would occur if the wetlands became drier, thereby lowering the water table, hence accelerating decomposition by micro-organisms under more aerobic and warmer conditions (Moore \& Knowles 1989, Oechel et al. 1993). Workers on the North Slope of Alaska have found that decomposition now dominates over photosynthesis on the tundra, and this area has become a source of carbon dioxide to the atmosphere 
(Oechel et al. 1993). Furthermore, their results suggest that tundra ecosystems may exert a positive feedback on carbon dioxide and greenhouse warming.

The measurement, and ultimately modelling, of the water balance of tundra and wetland ecosystems provides the means of predicting the hydrologic impact of climate change on these peatlands. This is significant since there is evidence relating increased carbon dioxide emission to the draining of wetlands. The work presented here details the measurement of the water balance of a Subarctic wetland for future modelling efforts; however, equipment was not put in place to measure the carbon budget.

The energy balance drives the global climate and is linked with the surface water balance through the latent heat flux (Lafleur et al. 1992). Although energy and water balance studies in Subarctic wetlands are sparse, many of the studies have recognized the importance of different terrain units. Recently, Rouse et al. (1992) explored the impacts of summer warming on the energy and water balance of a Subarctic fen by analyzing 3 climatically distinct summers. They concluded that wetland tundra displays feedback mechanisms that can offset the effects of moisture stress during summer climate warming. Lafleur et al. (1992) compared the energy balance differences between a sedge wetland and an open conifer forest at treeline with respect to their hydrologic impacts. They found that when moisture was not limiting, evaporation was highest over the wetland and sensible heating was highest over the forest. Roulet \& Woo (1986a) found the evaporation from a northern wetland was similar to that from a small lake. Rouse (1991) investigated the impact of Hudson Bay on the terrestrial climate of the Hudson Bay Lowland and found that cold air masses originating over the Bay vigorously suppressed evaporation from wetlands.

A complete water budget should involve independent and reliable estimates of each of the water balance components, which can be compared to residuals from the water balance to measure the overall accuracy of the water balance (Dooge 1975). Relatively few such complete water balance investigations have been conducted for any terrain type in Canada's northern latitudes. Of the major hydrological components, evaporative processes are the least understood, especially in northern areas (Prowse 1990). To address this problem, as well as the question of the role played by individual terrain types in the regional water balance, a detailed study was undertaken near Churchill, Manitoba, Canada, during the summer of 1991.

A research drainage basin, representative of the coastal region of the Hudson Bay Lowland, was established for long-term monitoring of the summertime water balance. Emphasis was placed on the measurement of evaporation given its importance in the energy and water balance. The determination of evaporation from each terrain type will allow an assessment of the relative impact each terrain type has in the energy and water balance. This will provide insight into potential effects of a change in surface cover due to prolonged climate change.

\section{STUDY AREA AND MEASUREMENT SITES}

\section{General geography and climate}

The research watershed is located $11 \mathrm{~km}$ east of Churchill, Manitoba, at $58^{\circ} 45^{\prime} \mathrm{N}, 93^{\circ} 57^{\prime} \mathrm{W}$ (Fig. 1a). This area is classified by the Ecoregions Working Group (EWG 1989) as being in the High Subarctic ecoclimatic region, and the Hudson Bay Lowland physiographic region. The Hudson Bay Lowland has the greatest concentration and largest extent of wetlands in North America and covers an area of approximately $474000 \mathrm{~km}^{2}$ (Rouse 1991). The High Subarctic wetland region is characterized by polygonal peat plateaus with local basin fens and shore fens. In areas that have recently emerged from Hudson Bay, polygon development is lacking. In the fens, small incipient palsas are a common and prominent feature. In the coastal zone, extensive fens dominated by Carex spp. are found (NWWG 1987).

Hudson Bay exerts a strong influence on the climate of the area, particularly through summer cooling, and is the primary reason the climate at this latitude is characterized as High Subarctic, with long cold winters, short cool summers and low annual precipitation. The average annual temperature is $-7.2^{\circ} \mathrm{C}$, and the average total precipitation is $402 \mathrm{~mm}$ (181 mm being derived from snow). The circulation within Hudson Bay is such that the sea ice usually forms first off the coast of Churchill in the fall and persists in this area the longest in the summer (Danielson 1969, Markham 1986). Hudson Bay's effect on the vegetation and climate of the Churchill area is reflected in the southerly position of the treeline and zone of continuous permafrost, which are roughly coincident in this part of Canada (Rouse 1991). The 30 yr mean temperature during the summer months (June, July and August) is only $9.8^{\circ} \mathrm{C}$ (Phillips 1990 ). Arctic species of plants normally found at higher latitudes are common in the Churchill area.

\section{Eastern Creek watershed}

Much of the $11.5 \mathrm{~km}^{2}$ coastal research basin is a wetland fen, drained by Eastern Creek which has Stygge Lake as its source and which terminates at Hudson Bay 


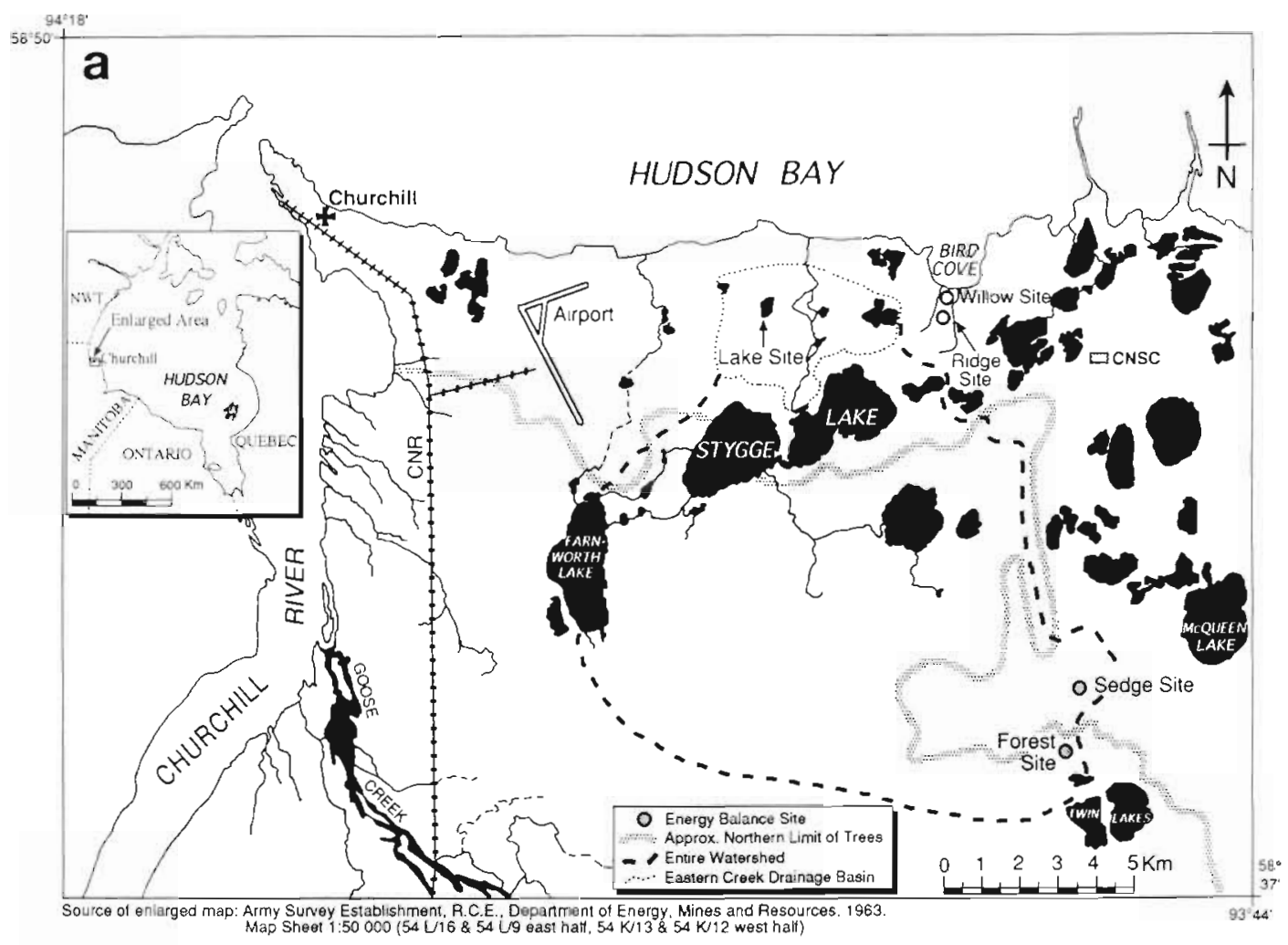

Fig. 1. Study area, Manitoba, Canada. (a) Location of the energy balance sites in and around the Eastern Creek drainage basin. (b) Eastern Creek drainage basin and location of the manual measurement stations. CNSC is the Churchill Northern Studies Centre

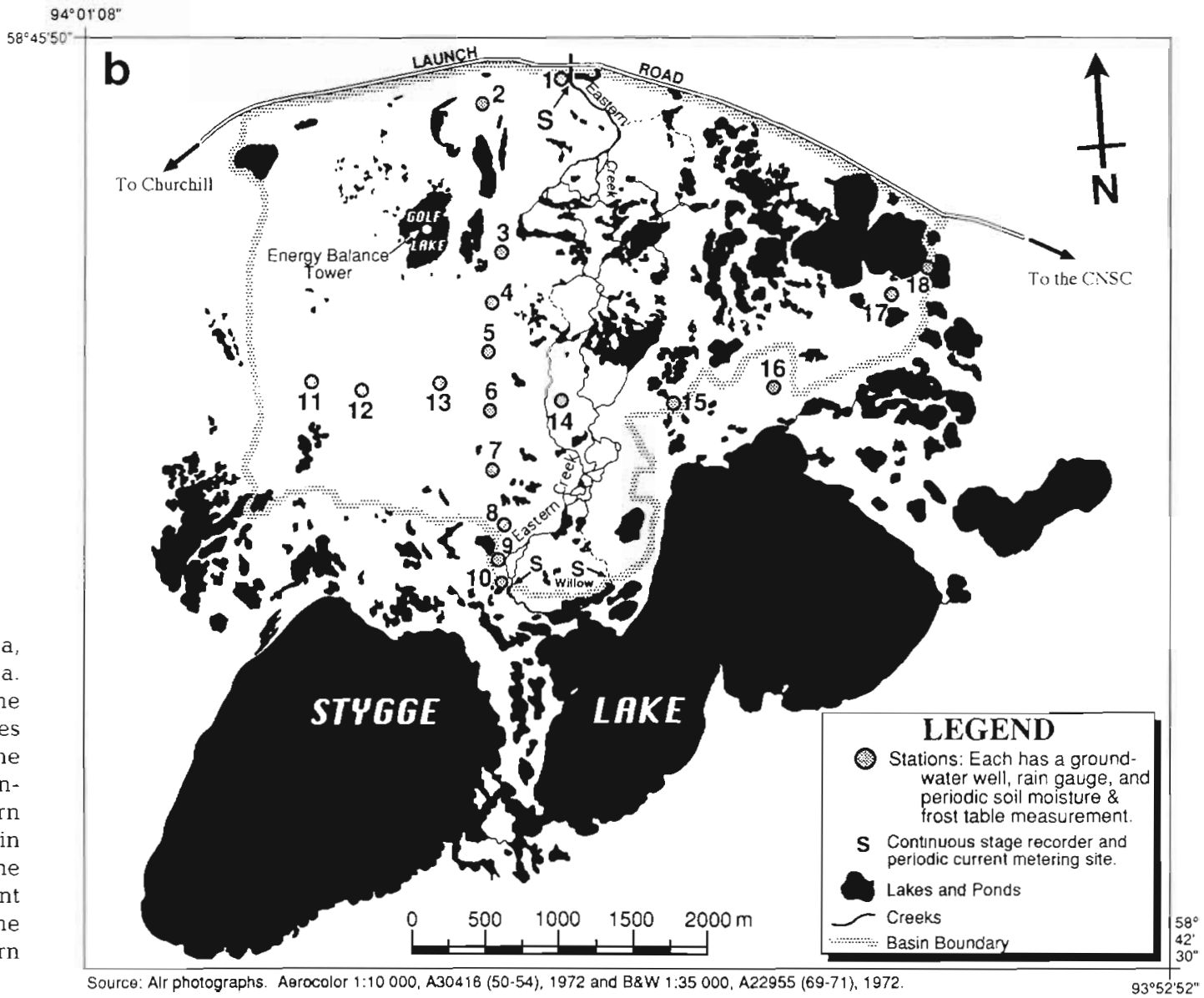


(Fig. 1b). The basin is underlain by continuous permafrost.

The study basin is a sub-catchment, and is referred to as the Eastern Creek drainage basin. The actual area from which Eastern Creek receives runoff water may be in excess of $100 \mathrm{~km}^{2}$ and includes an extensive area south of Stygge Lake. This portion of the true basin is characterized by wet tundra and extensive spruce-lichen woodlands. The regional gradient is very low over this area, having a difference in elevation of 1 to $1.5 \mathrm{~m} \mathrm{~km}^{-1}$. Most of the runoff generated feeds into several large lakes, which in turn are linked to Stygge Lake via creeks. The outflow of Stygge Lake (Eastern Creek) represents all the channellized runoff from the watershed south of Stygge Lake. After its emergence from Stygge Lake, Eastern Creek braids into numerous small channels and follows a tortuous course towards Hudson Bay. Although in the interior of the basin Eastern Creek's flow is diffuse, several hundred metres before the creek exits the basin the flow once again becomes concentrated into one large channel over $10 \mathrm{~m}$ wide. Monitoring the discharge exiting Stygge Lake made it possible to effectively define a sub-catchment which is confined to the area north of Stygge Lake.

The basin has the following advantages: accessibility is good, Eastern Creek is one of the few perennial streams in the area that has substantial flow throughout summer, and the basin contains the terrain types commonly found within these coastal wetlands.

\section{Measurement sites}

Rainfall, water and frost table depth, and soil moisture data were collected from 18 stations located along 2 transects across the basin (Fig. 1b). Stream discharge was measured at the source (Willow Creek and Upper Eastern Creek) and near the terminus of Eastern Creek (Lower Eastern Creek). For evapotranspiration and the surface energy balance measurement, most of the instrumentation was located just outside the basin where suitably extensive terrain units, representative of those found within basin, were available.

Ongoing research by Dr P. Lafleur for a spruce-tamarack forest near Twin Lakes provided energy balance data which were representative of Subarctic open forest. The energy balance of open forest was determined at a tower which was located at the north edge of an extensive and contiguous tract of open forest. The forest is ap- proximately $12 \mathrm{~km}$ southeast of the study basin (Fig. 1a) and is described in detail in Lafleur et al. (1992). The energy balance of coastal dwarf willowbirch forest was measured $3 \mathrm{~km}$ east of the study basin at a site described by Blanken \& Rouse (1994). Measurements over wet sedge tundra were made $11 \mathrm{~km}$ southeast of the study basin at a site described in detail by Weick \& Rouse (1991) and Wessel \& Rouse (1994). The energy balance was also measured over lichen-heath (Ridge site in Fig. 1a), $400 \mathrm{~m}$ south of the Willow site. Evaporation from open water was calculated from data collected at the center of Golf Lake in the study basin.

\section{Terrain types and vegetation}

Fig. 2 shows the coverage of each terrain type within the basin, and Table 1 lists their area and measurement stations.

The sedge-dominated wetlands are generally a hummocky terrain in which Carex aquatilis is the dominant species. The water table is typically at or near the surface giving rise to either standing water or soil near saturation (volumetric water contents of 80 to $90 \%$ ) in the hollows (Wessel \& Rouse 1994). The raised relief of the hummocks allows relatively good drainage and therefore lower soil moisture than the hollows (50 to $60 \%$ ). The hummocks are dominated by C. aquatilis and other sedges, mosses, grasses, Ledum decumbens and some heath species. In addition to the hummockhollow surface, there are extensive sedge meadows within the basin that are flatter and have a more lush coverage of $C$. aquatilis than those found around the instrumented Sedge site. Most of the sedge wetlands are fens, but some isolated bogs (ombrotrophic) are observed in the western half of the basin. Peat depths are generally greatest adjacent to creeks and in areas that are continually wet in the sedge-dominated wetland. At the instrumented Sedge site there is approximately $0.35 \mathrm{~m}$ of peat overlying poorly sorted glaciomarine silts (Rouse et al. 1992).

Table 1. Areal coverage of the terrain types found within the Eastern Creek drainage basin and the location of the manual measurement stations

\begin{tabular}{|lcccc|}
\hline Terrain type & $\begin{array}{c}\text { Station no. on } \\
\text { each terrain type }\end{array}$ & & \multicolumn{2}{c|}{$\begin{array}{c}\text { Areal coverage of } \\
\text { the terrain units }\end{array}$} \\
\hline Sedge-dominated wetlands & $4,5,6,7,11,13,16,17$ & $5.37 \mathrm{~km}^{2}$ & $46.5 \%$ \\
Upland lichen-heath & $3,9,12$ & $2.08 \mathrm{~km}^{2}$ & $18.0 \%$ \\
Lakes and ponds & Golf Lake & $1.90 \mathrm{~km}^{2}$ & $16.5 \%$ \\
Willow-birch wetland & $1,10,14$ & $1.73 \mathrm{~km}^{2}$ & $15.0 \%$ \\
Open spruce forest & $2,8,15,18$ & $0.46 \mathrm{~km}^{2}$ & $4.0 \%$ \\
& & Total: & $11.54 \mathrm{~km}^{2}$ & $100 \%$ \\
& & & & \\
\hline
\end{tabular}




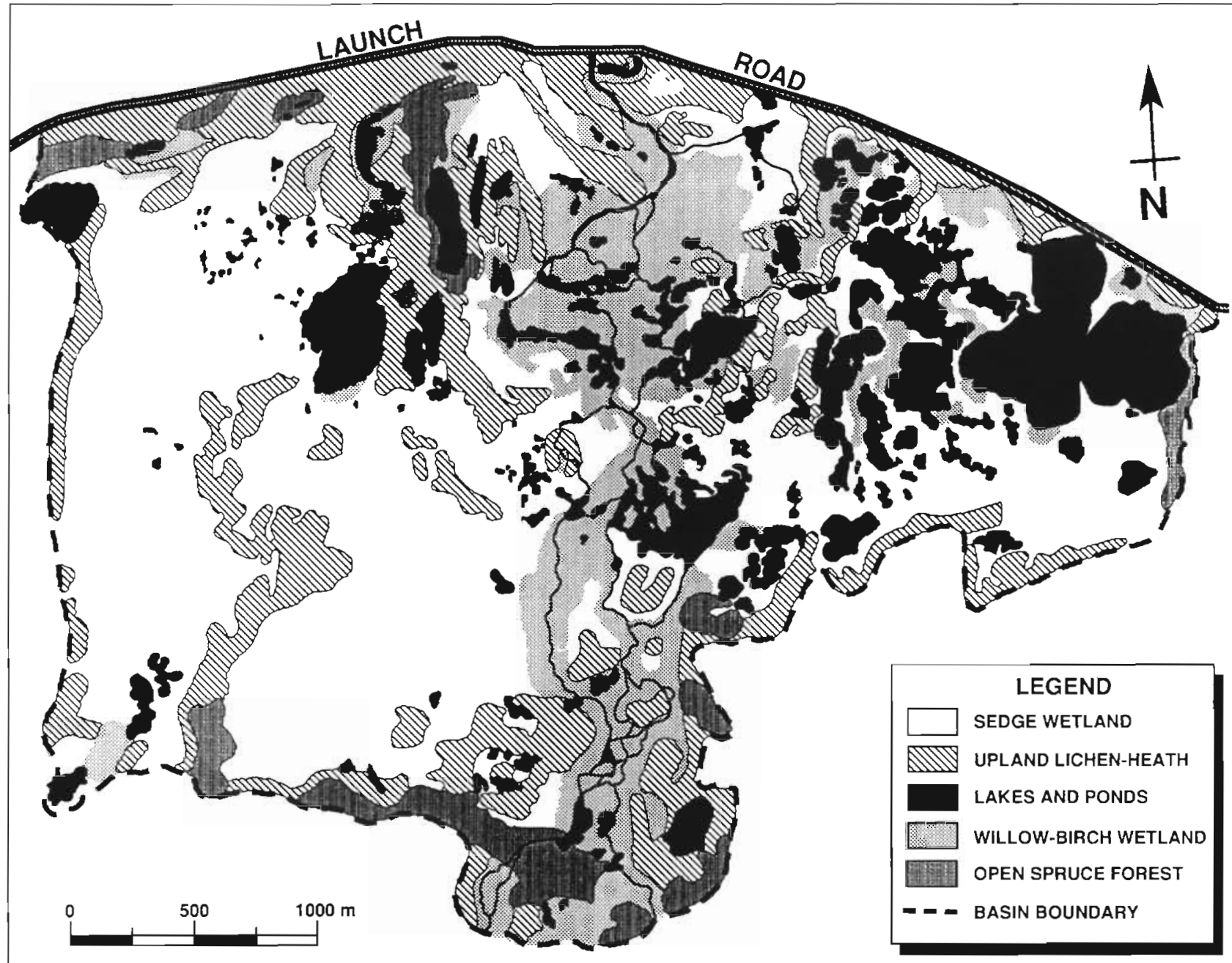

SOURCE: AIR PHOTOGRAPHS. AEROCOLOR 1 10.000. A30416 (50-54), 1972. B\&W 1:35,000, A22955 (69-71), 1972.

Fig. 2. Terrain types within the Eastern Creek drainage basin

The upland lichen-heath classification includes raised beach ridges, palsas and plateaus which have high sand, gravel and boulder contents, and a thin organic mantle. The larger ridges rise over $2 \mathrm{~m}$ above the surrounding wetlands, are elongated in shape and have a thin vegetation cover. On the upland plateaus and palsas a thicker cover of lichen, moss, vascular shrubs and peat is found. The poorly developed soils of the well-drained uplands support only primitive or hardy xerophytic plants, particularly lichen and heath species. The dominant lichens are Cladina stellaris and Cladina rangiferina which can form thick extensive mats. Other common lichen species are Cetraria nivalis, Cetraria cucullata, Alectoria ochroleuca and Alectoria nigricans. The hydrological significance of lichen mats lies in the fact they can intercept substantial amounts of rainfall, thus allowing this water to be subsequently rapidly evaporated (Bello \& Arama
1989). The most common heath and mat-forming species include Dryas integrifolia, Ledum decumbens, Rhododendron lapponicum, Empetrum nigrum, Arctostaphylos alpina, and Andromeda polifolia.

Tundra ponds and lakes are conspicuous features in the Hudson Bay Lowland and in areas can comprise over $40 \%$ of the surface area (Bello \& Smith 1990). The deepest lakes in the area rarely exceed $2 \mathrm{~m}$ in depth and most are less than $0.5 \mathrm{~m}$ deep and less than $200 \mathrm{~m}$ in diameter. Many of these water bodies merely occupy topographic lows that flood and dry up regularly, and as a result, the area of water surfaces frequently expands and contracts depending on moisture conditions.

The willow- and birch-dominated wetland terrain type is a mosaic of several vegetation assemblages. In the wetter areas, Salix planifolia is the dominant willow and is commonly accompanied by Carex aquatilis 
and Salix candida. The willows prefer wet areas along the perimeter of most lakes and extensive areas through the middle of the basin where Eastern Creek flows (Fig. 2). In drier areas farther away from ponds and creeks, Betula glandulosa, Myrica gale and Salix reticulata are more prevalent. The soils are composed of black peaty organic material that is tightly bound by the roots of willows and grasses. This is overlain by a thick litter layer of dead leaves, roots and grass that can accumulate to depths in excess of $5 \mathrm{~cm}$.

Open spruce forest and woodland areas occupy only a small proportion of the basin. The coastal wetland soils become increasingly cool, wet and nutrient-limited with proximity to Hudson Bay, prohibiting extensive seedling establishment (Scott et al. 1987). Consequently, only small islands of forest are found near the coast of Hudson Bay, and these tend to be on the drier upland areas. The instrumented Forest site (Fig. 1a) covers a large glacial kame deposit on which the dominant tree species are Larix laricina, Picea mariana and Picea glauca (Lafleur et al. 1992). The energy balance site at Twin Lakes will be referred to as the 'Forest site', while similar terrain units in the study basin will be referred to as 'open forest'. The woodland areas within the study basin are somewhat more open and less productive than the instrumented site and are restricted to ridges and upland areas. $P$. glauca is the most common species of tree. The soils have high sand and gravel contents with $20 \%$ organic contents in the top $5 \mathrm{~cm}$ (Rouse 1984a). Lichen and heath species invade much of the forest floor along with herbaceous plants and small shrubs.

\section{METHODS}

\section{Terrain unit identification}

Criteria to subdivide the basin into distinct terrain types were based on such factors as topography, soils, vegetation, and hydrology. Air photographs and field observations were used to categorize the terrain types in the basin. To estimate the areal extent of each of the 5 terrain units, a large 1:10000 colour map was constructed and planimetered to give the distribution of lakes and ponds, willow-birch wetlands, sedge-dominated wetlands, upland lichen-heath, and open forest.

\section{The water balance}

For the first season of operation, measurement of the water balance spanned the growing season, which comprises the months of June, July and August. From June 21 to August 18, data were gathered for all aspects of the water balance simultaneously. Since the water balance was computed for the post-melt season, quantifying the input of water due to the accumulation and melt of snowfall was not necessary.

In a water balance, the difference between the inputs and outputs equals the amount of water stored within, or depleted from, the system. Extending a boxmodel approach to a drainage basin gives

$$
P+R O_{1}+G W_{1}-\left(E T+R O_{0}+G W_{0}\right)=\Delta S
$$

where $P$ is precipitation, $R O_{i}$ is surface water input, $G W_{\mathrm{i}}$ is groundwater input, $E T$ is evapotranspiration, $R O_{0}$ is runoff leaving the basin, $G W_{0}$ is groundwater leaving the basin, and $\Delta S$ represents the change in storage in the basin (increases being positive) including surface water, groundwater and soil moisture fluctuations.

In a well-defined drainage basin, there should be no surface runoff across the drainage divide unless a stream enters the basin $\left(R O_{\mathrm{i}}\right)$, in which case the streamflow must be monitored. The hydraulic gradient in wetlands is typically very small and allows only a negligible amount of groundwater to flow across the basin boundary. Furthermore, the existence of continuous permafrost eliminates any exchange of water to or from a regional groundwater system. The water balance of a wetland, drained by a stream and underlain by continuous permafrost, may be written

$$
P-E T-R O=\Delta S
$$

where $G W_{1}$ and $G W_{0}$ across the basin boundary are assumed to be negligible given the flat nature of the wetlands, and are thus omitted from this equation. When calculating the water balance on a basin scale, $E T$ is the areally weighted average evapotranspiration of the 5 terrain types. RO represents surface runoff that is generated within the basin and lost to the system at the outflow of the creek:

$$
R O=R O_{0}-R O_{\mathrm{i}}
$$

Contained within the $R O$ term is groundwater discharge and seasonal frost melt water that seeps into the creek from the adjacent banks.

In this study, 'runoff' is defined as water that originates within the Eastern Creek drainage basin and exits the watershed via Eastern Creek as streamflow. The difference between the outflow under Launch Road and the inflow from Stygge Lake (Fig. 1b) represents the runoff generated within the study basin. This runoff is derived from a variety of different sources, the determination of which was beyond the scope of this project. The runoff term (RO) as defined in Eq. (3) represents the net result of all these sources.

Discharge was measured using standard techniques combining continuous stage records (Stevens Type-F) 
with periodic current-metering. Equipment was put in place at the inflow and outflow of the main branch of Eastern Creek as well as near the source of Willow Creek. At these locations the velocity-area method was used to calculate the instantaneous discharge at various stages with Price-type current meters. The bedform of the creeks did not change over the measurement period.

The input of precipitation to the drainage basin was measured by 18 standard rain gauges located at the stations along 2 transects crossing the basin. Rainfall intensity was recorded by a tipping bucket rain gauge located at the Willow site. The rainfall intensity information was useful when partitioning rain events that spanned several days.

The location and progression of the frost table throughout the thaw season determines the storage capacity for liquid water. At weekly intervals for as long as conditions permitted, the depth of the frost table was measured at each of the 18 stations using a steel rod probe. The average of several frost table measurements was calculated for each of the 18 stations.

Attempts to quantify the relation between storage and the water table generally involve the concept of specific yield. Specific yield $\left(Y_{\mathrm{s}}\right)$ is the ratio of the volume of water that will drain by gravity from totally saturated soil to the volume of the soil block (Price 1985). For a given fluctuation of the water table $(\Delta W L)$, the change in groundwater storage $\left(\Delta S_{g}\right)$ over the interval can be determined by

$$
\Delta S_{\mathrm{g}}=\Delta W L\left(Y_{\mathrm{s}}\right)
$$

The fluctuation of the water table was monitored each morning inside perforated ABS plastic pipes ( $5 \mathrm{~cm}$ dia.) that had been inserted into augured holes at each of the 18 stations. To calculate the basin-averaged $\Delta S_{\mathrm{g}}$, it was first calculated individually for each well using Eq. (4). If the water table is above the soil surface then $\Delta S_{g}=\Delta W L$. The average $\Delta S_{g}$ for the appropriate well groupings was then calculated for each terrain type, and finally each terrain type was weighted by its areal extent and summed to give the basin $\triangle S_{g}$

Soil moisture analysis was carried out weekly at each of the 18 stations. Steel sampling cans were used to cut and contain soil plugs taken 5 to $10 \mathrm{~cm}$ below the surface. A long, thin knife was used around the sampling can during insertion and across its mouth when full to prevent excessive compaction and deformation of the sample. Immediately after completion of field work, all samples were weighed then put into a drying oven $\left(100^{\circ} \mathrm{C}\right)$ for at least $24 \mathrm{~h}$. After drying, the weight of the samples was recorded and volumetric soil moisture calculations performed based on the wet and overdried weights and the volume of the soil plug. Soil water contents were expressed on a volumetric basis because organic soils have a wide range of bulk densities (Boelter 1975). Using the various sample weights (including saturated weight), specific yield, soil bulk density and porosity were also calculated.

\section{The energy balance}

It was necessary to measure the energy balance of each terrain type to obtain the evapotranspiration (given by the latent heat flux). The energy balance can be expressed as

$$
Q^{\cdot}=Q_{E}+Q_{H}+Q_{G}
$$

in which $Q^{*}$ is net radiation, $Q_{E}$ is the latent heat flux, $Q_{H}$ is the sensible heat flux and $Q_{G}$ is the ground heat flux. At each site $Q^{*}$ was measured using Middleton net pyrradiometers (Middleton, Inc., Medos, Melbourne, Australia) mounted near the top of the towers and extending horizontally $1.5 \mathrm{~m}$ from the masts.

To determine $Q_{H}$ and $Q_{E}$, the Bowen ratio energy balance (BREB) approach was used most of ten where gradients of temperature and vapour pressure were measured in a vertical profile on energy balance towers. The BREB approach used in this study follows that of Rouse et al. (1992). Temperature and vapour pressures were measured at various heights using aspirated psychrometers. A 6-level profile system was used at the Willow, Ridge and Sedge sites, 5 levels were used at the Forest site, and 3 levels were employed over the Golf Lake site.

$Q_{\mathrm{G}}$ for the land sites was determined using calorimetric calculations for daily totals from soil temperature rods extending to depths ranging from 0.4 to $1.25 \mathrm{~m}$. Daily totals were then divided into half-hourly values according to Middleton soil heat flux plate measurements. This was necessary because the use of only heat flow plates in organic permafrost terrain can seriously underestimate the actual flux. Details of this methodology are given in Rouse (1984b) and Halliwell $\&$ Rouse (1987).

Implementation of the BREB method for measuring the evaporation from tundra lakes is given by Bello \& Smith (1990). If the lake is isothermal, as most shallow tundra lakes are except on completely calm days (Bello \& Smith 1990), the calculation of the heat storage term $\left(Q_{W}\right)$ is greatly simplified because surface temperature represents the temperature throughout the mixed layer. Under these conditions, the mean depth of the lake becomes the thickness of the layer over which the storage term is integrated. The surface temperature of Golf Lake was obtained by a thermocouple sealed and wrapped in aluminized tape which was affixed to the bottom of a Styrofoam float. To accurately determine 
the mean lake depth, a comprehensive bathymetric survey was undertaken

When the BREB approach becomes inaccurate due to very small vapour pressure gradients such as at sunrise and sunset, equations based on an aerodynamic approach are used for the calculation of the turbulent fluxes. This application and its reliability are developed in detail in Halliwell \& Rouse (1989). To obtain the vertical wind speed gradients for aerodynamic flux calculations, Gill cup anemometers (R. M. Young Co., Traverse City, MI, USA) were used in a vertical profile on the energy balance towers.

All energy balance towers used identical types of radiation instruments, anemometers, wind vanes, and temperature sensors. All sites, except the Forest, also had identically constructed psychrometer systems. The energy balance tower in Golf Lake was located in the center of the 550 by $350 \mathrm{~m}$ lake in $1.2 \mathrm{~m}$ of water. For evaporation calculations that are sensitive to sensor height, the level of the instruments above the surface of the water was calculated daily based on the level on a staff gauge near the shore. Instruments at the energy balance sites were sampled by the dataloggers every $10 \mathrm{~s}$, and the measurements stored as half-hour averages.

Pasquill (1972) detailed the importance of satisfying certain fetch requirements when making microclimatological measurements over different surfaces. Assuming the surface over which the measurements are taken is homogeneous, the height of the instruments should not exceed $1 \%$ of the fetch for the measurements to be considered representative of the properties of that surface (i.e. in the fully adjusted boundary layer). A 1:100 height:fetch ratio was satisfied at all measurement levels for all energy balance sites except the Willow site, which had restrictive fetches for north and south wind directions. Under these conditions only the lowest 2 instrument levels had a 1:100 height: fetch ratio; however, under easterly or westerly winds all instrument levels satisfied the 1:100 fetch requirement. Since the willow surface is relatively rough, height:fetch ratios of less than 1:100 may still allow instruments to be in the fully adjusted boundary layer.

When extrapolating the evapotranspiration from the research sites to similar terrain types in the study basin, an assumption is made that full boundary layer adjustment also applies to each terrain unit within the basin. Since many of the terrain units in the basin are limited in areal extent, this assumption is often not satisfied, and advective effects between the wet lowland and dry upland surfaces can be large (see for example Bello \& Smith 1990). It is assumed that advective influences at the upwind edge of a small terrain unit will be compensated at the downwind side by influencing the adjacent terrain unit. Thus over the area of a basin, mesoscale advective effects will be ignored when considering basin-scale evapotranspiration.

\section{RESULTS AND DISCUSSION}

\section{Temperature and precipitation}

The summer of 1991 was a season of extremes. Comparisons of climatological data collected in 1991 to the long term 'normals' indicate the summer to be atypical with respect to both temperature and precipitation.

During the period the water balance was measured, average monthly temperatures were more than $3^{\circ} \mathrm{C}$ above normal. The spatial variability of rainfall within the study basin proved to be small (the mean standard deviation of rainfall measured by the 18 rain gauges for 28 rain events was very small at $0.63 \mathrm{~mm}$ ); therefore the arithmetic mean of the 18 rain gauges was used to give the average input of precipitation for the whole basin. There were less than normal amounts of rainfall during the later part of June, nearly 4 times the normal amount of rain in July, and less than normal amounts of rainfall during the first half of August. Between June 12 and August $24,219 \mathrm{~mm}$ of rainfall was measured during 28 rain events.

\section{Groundwater storage}

Well records and soil moisture were the primary variables used to track the change in groundwater storage $\left(\Delta S_{g}\right)$. Of all the variables in the water balance, $\Delta S_{9}$ proved the most difficult to calculate. Although all the wells responded to wet and dry episodes in a similar fashion, the magnitude of the rise or drop in the water table was site-dependent. As well, the water table at each station was at a different depth relative to the surface, making intercomparisons difficult. Instead of tracking water table depths relative to the surface for all the stations, for comparative purposes, the change in depth of the water table for each terrain type was examined. Generally, wells on the same terrain type showed a similar amount of change in the displacement of the water table over the course of $24 \mathrm{~h}$. The stations located in the sedge wetland exhibited a better intracorrelation between wells than for the other terrain types. On and immediately subsequent to rain days, the water table at these sites often rose substantially due to the high soil moisture in the unsaturated zone. Other terrain types showed similar patterns although the magnitude of the changes in water table elevations was greater, especially in the open forest and upland lichen-heath. In these better-drained sites, the water table typically dropped faster during drying cycles and rose more 
rapidly and in greater magnitude immediately after large rain events. This is due to subsurface gravelly materials having an overall lower porosity than the overlying soil. With less void space by volume for the water to fill, the water table rises and quickly falls during wetting and drying cycles. The cumulative effect of the daily changes in the position of the water table for each terrain type is shown in Fig. 3. Data for a particular terrain type were excluded when the water table dropped below the base of the well and the depth of the water table could not be measured. For this reason, water table depths in the upland lichen-heath and open forest may be underestimated.

All wells showed a lower water table at the end of the study period than at the beginning. The open forest and upland lichenheath displayed the most erratic fluctuations

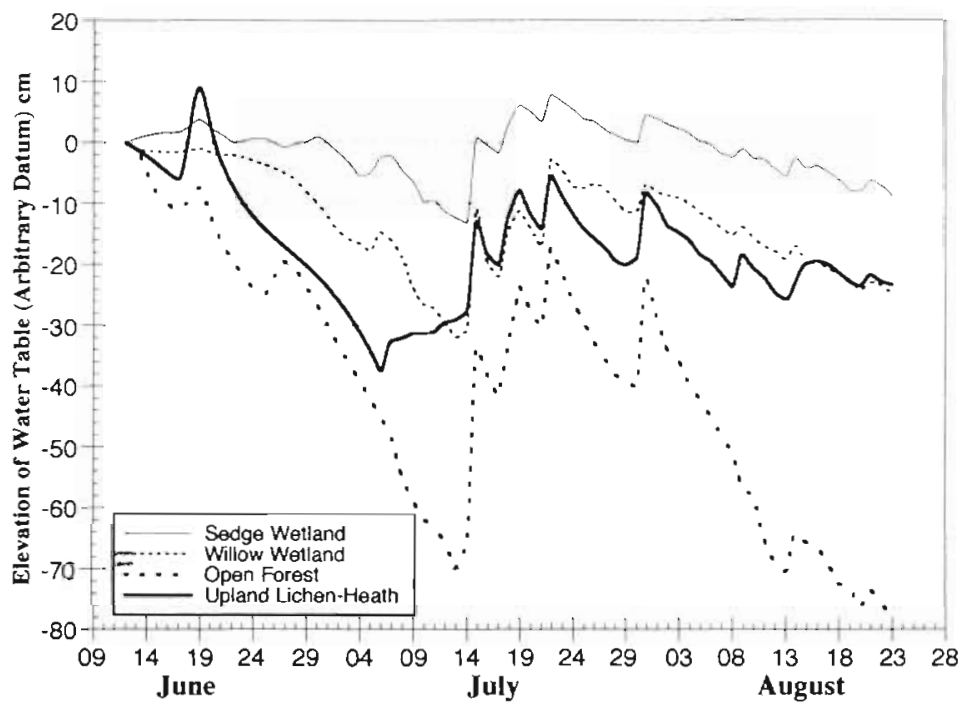

Fig. 3. Cumulative changes in water table depth based on mean daily fluctuations on each of the terrain types, referenced to June 12

in their water tables. The water table was lowest under the open forest, where by the end of the field season it lay more than $0.8 \mathrm{~m}$ below the surface. Since the open forest and lichen-heath wells were located midway up the slopes, the water table was undoubtedly deeper beneath the surface at the highest parts of the ridges.

On average, the water table at the willow and lichenheath sites dropped $0.26 \mathrm{~m}$ over the field season. The water table of the sedge wetland dropped only $0.10 \mathrm{~m}$. Since in the sedge wetlands the water table commonly rose to the surface following heavy rains, its average depth below the surface was only $0.06 \mathrm{~m}$ over the season.

\section{Soil moisture}

Frozen ground in the wetlands, and rocks in the upland plateaus and forest ridges, prohibited a proper analysis of soil moisture with depth. This omission in the sedge and willow wetlands is not considered to be serious since the unsaturated zone was generally in the upper 10 to $20 \mathrm{~cm}$ of soil where the soil samples were taken from. Since the water table was generally below the organic layer in the open forest and upland lichenheath terrains, there were important sources for error that affected the measurement of soil moisture and the calculation of change in groundwater storage (detailed in the section 'Water balance' below).

The seasonally averaged soil moisture for each terrain type is shown in Fig. 4. The average soil moisture at each of the 8 sedge stations varied little both between each station and within each station. The need for more samples from the willow, upland lichen-heath and open forest terrain types is apparent given the large variations in soil moisture between stations and within each station.

The seasonal average of $85 \%$ water content by volume for the sedge wetland soils (Fig. 4) compares closely to the $83 \%$ calculated for the hollows of the instrumented Sedge site (Wessel \& Rouse 1994). It is important that the soil moisture in the sedge wetland be determined accurately since this terrain type comprises over $46 \%$ of the basin's area. The willow wetland has the second highest average soil moisture, but the average of $67 \%$ is likely underestimated given the lack of wells in the wetter and less accessible interior of the basin, and the sandy nature of Station 1 along the creek. The highly variable topography, soil composi-

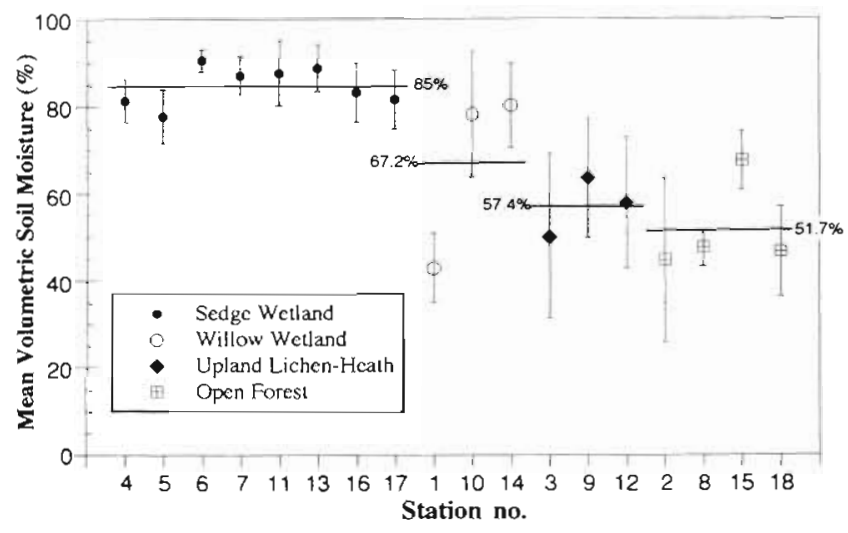

Fig. 4. Seasonally averaged volumetric soil moisture in the surface soil layers at each of the 18 stations. Error bars indicate the standard deviation about each station's mean, and horizontal lines give the average soil moisture for each terrain type 


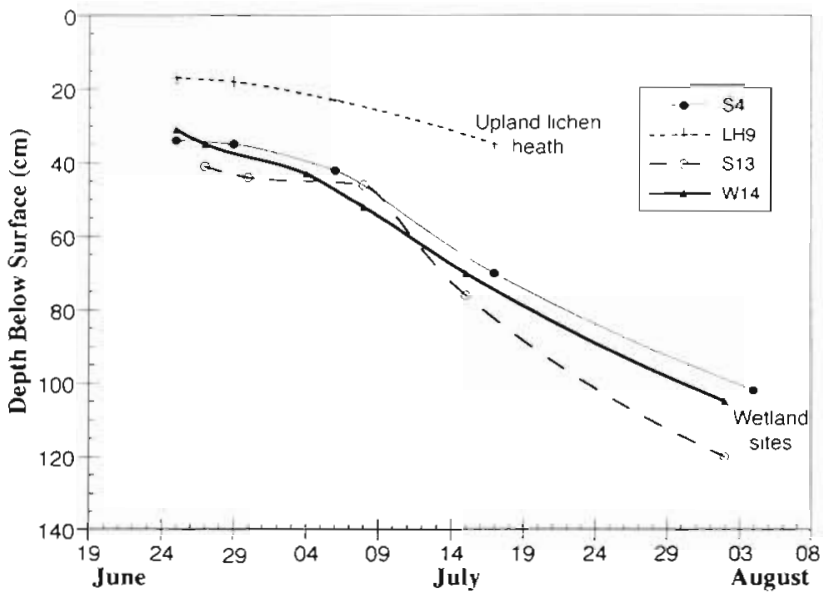

Fig. 5. Seasonal active layer development as indicated by frost table depth for selected stations on lichen-heath (LH9) and wetland terrain types (S4, S13 and W14). Stations that provided the most reliable data are used in the plot

tion and better drainage on both the open forest and upland lichen-heath sites is responsible for the lower average soil moisture ( 40 to $60 \%$ ) and the greater spatial variability.

Specific yield $\left(Y_{\mathrm{s}}\right)$ was also calculated for the sites. Eggelsmann (1975) states that gravity drains off about 3 to $10 \%$ by volume of peat soil pore space. Similar values were measured for the willow and sedge wetland soil which had the lowest $Y_{\mathrm{s}}$. The mean $Y_{\mathrm{s}}$ for the sedge wetland of $6.5 \%$ is similar to that found by Boelter (1975) for well-decomposed peat, and Roulet \& Woo (1986b) who measured $5.7 \%$ for peat. The peaty soils of the willow and sedge wetlands have the lowest $Y_{\mathrm{s}}$. The greater litter and sand content of the open forest and upland lichen-heath soils gave a higher $Y_{\mathrm{s}}$ (14 and $15 \%$, respectively) but these values are quite low compared to the material below. The high content of sand, gravel and boulders below the top $10 \mathrm{~cm}$ of soil will give an overall higher bulk density, lower porosity and a higher $Y_{\mathrm{s}}$. It was not possible to measure these parameters in the field at the required depths; however, since the water table was normally in this sand and cobble region, a representative $Y_{\mathrm{s}}$ was needed to calculate $\Delta S_{\mathrm{g}}$. In coarse material such as that under the surface of the ridges and plateaus, $Y_{\mathrm{s}}$ approaches the porosity. Therefore, when the water table was below the top $0.1 \mathrm{~m}$ of soil at the open forest and upland lichen-heath sites, a $Y_{\mathrm{s}}$ of $30 \%$ was used to calculate $\Delta S_{\mathrm{g}}$.

\section{Active layer development}

Active layer development is very important in Subarctic wetlands. A significant proportion of net runoff is stored within the still-frozen part of the active layer early in the thaw season, and it is slowly released when the active layer approaches its maximum depth (Wright 1982). Depth to the frost table was highly variable. Obstruction of the probe by stones in the deeper soil layers caused all of the frost table measurements to be suspended after August 4 and earlier for the lichenheath and open forest sites. Fig. 5 contains data that are considered to be realistic (i.e. the averages are a result of relatively consistent frost table depths at each station). The measurements at the open forest stations are not considered reliable enough to present in Fig. 5.

Only a shallow active layer develops under the lichen-heath plateaus (Fig. 5). Dry soils coupled with the high albedo and thermal insulation provided by lichen mats are the main factors contributing to the shallow frost table. In contrast, the sedge and willow sites developed active layers over a metre deep by the beginning of August. Wet darker surfaces, giving rise to low albedos, and the higher thermal conductivity of water are the main factors contributing to relatively thick active layers in the wetlands.

\section{Stream discharge and runofif}

The stream discharges at Willow, Upper and Lower Eastern Creek were used to calculate the runoff that originated within the Eastern Creek drainage basin. Over the interval the water balance was computed, there was approximately $211 \mathrm{~mm}$ of runoff. The assumption that the discharge at Willow and Upper Eastern Creek represented all of the water input to the study basin may not have been valid for the whole field season. For this reason, the calculated runoff is likely overestimated. The details of adjusting the runoff are elaborated on in the section 'Water balance' below.

Following heavy rainfalls, large amounts of runoff $\left(R O=R O_{0}-R O_{1}\right)$ were generated from the Eastern Creek basin (Fig. 6). The wetland regions of the experimental drainage basin can be major sources and efficient conveyors of water to Eastern Creek, depending on the moisture status of the peat. When the peatlands are near saturation and the water table is near the surface, the response of Eastern Creek to rainfall is rapid and large (see for example July 23). In contrast, after prolonged drought periods when the peat near the surface is drier and the water table draws down, the peatlands act as a sponge and absorb much of the rainfall and buffer the stream, allowing only small amounts of water to reach the creek (see for example July 15). Given the flat topography of the wetland, groundwater is a minor contributor of water to Eastern Creek compared to surface runoff. Due to the high infiltration capacity of peat, for surface runoff to occur, the water 


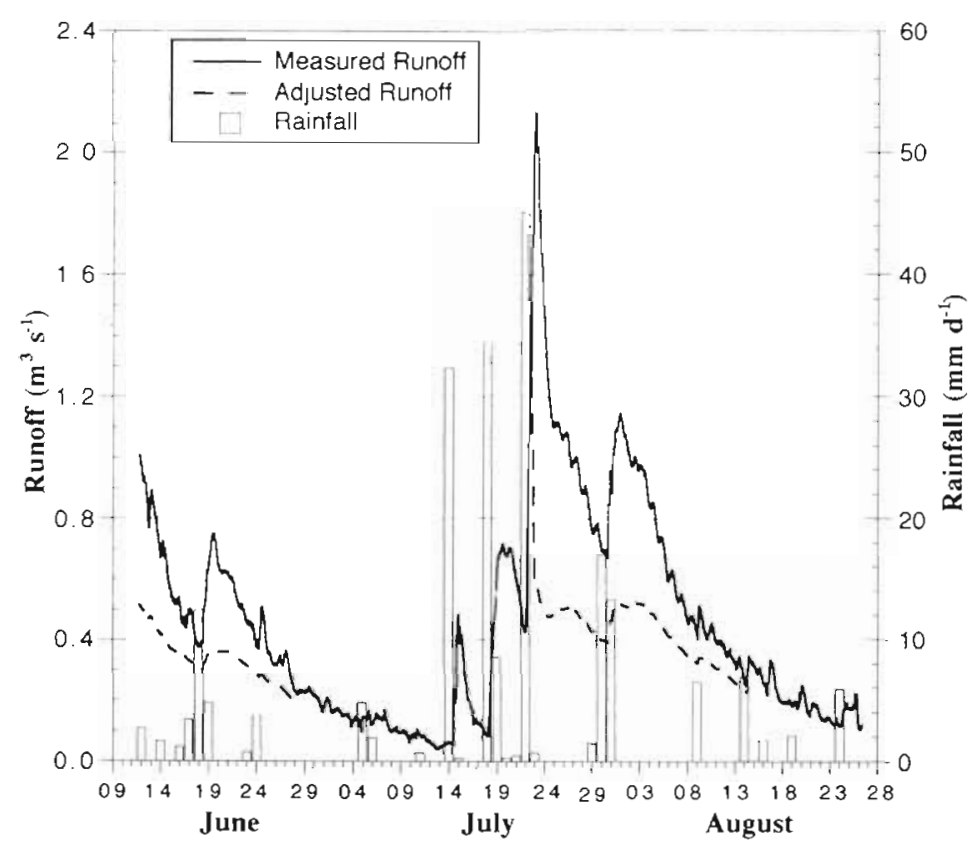

Fig. 6. Seasonal pattern of discharge generated within, and exiting from, the Eastern Creek drainage basin, with rainfall superimposed basin occupies only about $10 \%$ of the area of the total watershed. Although there is a possibility the runoff from the Eastern Creek basin may be overestimated, the results indicate that this basin is responding as an efficient drainage basin, whereas the region south of Stygge Lake has a poorly integrated drainage pattern

\section{Energy balance of lakes}

In many respects, the energy balance of shallow tundra lakes, as represented by Golf Lake, is unique compared to the land sites (Table 2). Diurnally, land surfaces can utilize up to $18 \%$ of $Q^{*}$ in $Q_{G}$, which is sizable, but $Q_{W}$ for the lakes is normally much larger. This is true of Golf Lake. Most of the daytime $Q^{*}$ was partitioned between $Q_{E}$ and $Q_{W}$, while $Q_{H}$ was a relatively minor component in the energy balance.

The high thermal inertia of water bodies, relative to land surfaces, causes them to warm up more slowly during the day and

table must rise near or above the surface. This activates the numerous small ponds and feeder channels that empty into Eastern Creek. The extensive drainage network through the middle of the basin provides the means and capacity to collect large quantities of water and quickly transport it out of the basin. This feature makes Eastern Creek drainage basin unique compared to areas of the broader watershed south of Stygge Lake.

During rain-free periods, the discharge of Lower Eastern Creek was approximately twice that of Upper Eastern Creek - which in turn had a discharge approximately twice that of Willow Creek. The ratio of the total discharge generated from within the study basin to that generated from the entire watershed drained by Eastern Creek reveals that approximately $20 \%$ of the water came from the Eastern Creek drainage basin. This is significant considering the study gradually release this stored heat over the course of the night. The wide range of temperatures experienced on land surfaces is in contrast to the comparatively modest temperature fluctuations that water bodies undergo. However, small temperature changes in a lake over time can result in large $Q_{W}$ given the high specific heat of water, and the isothermal conditions that prevail in tundra lakes extend this temperature change through the whole profile.

During summer daylight periods, the cool water bodies generally act as a large sink for heat, and since $Q_{E}$ normally proceeds at a high rate, little energy is available to go into warming the atmosphere $\left(Q_{H}\right)$. During the day, the sensible heat flux over Golf Lake was commonly directed towards the lake surface $\left(-Q_{H}\right)$ which is indicative of advective conditions. Another indicator of advection is high Priestley-Taylor $\alpha$ values (Priestley \& Taylor 1972). Golf Lake had a seasonal average $\alpha=$

Table 2. Energy balance $\left(\mathrm{W} \mathrm{m}^{-2}\right.$ ) of each terrain type (June 21 to August 18 ). $Q^{*}$ is net radiation, $Q_{E}$ the latent heat flux, $Q_{H}$ the sensible heat flux, $Q_{G}$ the soil heat flux, and $\beta$ the Bowen ratio. Flux ratios and $\beta$ are unitless

\begin{tabular}{|c|c|c|c|c|c|c|c|c|}
\hline Terrain type & $Q^{\bullet}$ & $Q_{E}$ & $Q_{\mathrm{H}}$ & $Q_{\mathrm{G}}$ & $Q_{E} / Q^{\bullet}$ & $Q_{\mathrm{H}} / Q^{*}$ & $Q_{\mathrm{G}} / Q^{\circ}$ & $\beta$ \\
\hline Sedge-dominated wetlands & 142.8 & 101.9 & 28.4 & 13.3 & 0.71 & 0.20 & 0.09 & 0.28 \\
\hline Upland lichen-heath & 1.32 .9 & 66.6 & 43.9 & 24.5 & 0.49 & 0.33 & 0.18 & 0.68 \\
\hline Golf Lake & 165.3 & 136.6 & 17.1 & 5.5 & 0.83 & 0.10 & 0.07 & 0.13 \\
\hline Willow-birch wetland & 143.8 & 92.0 & 30.4 & 20.2 & 0.65 & 0.21 & 0.14 & 0.33 \\
\hline Open spruce forest & 146.3 & 93.2 & 35.2 & 14.5 & 0.66 & 0.24 & 0.10 & 0.36 \\
\hline
\end{tabular}


1.58, well above the purported 1.26 for open water. Evaporation from shallow lakes is closely controlled by variations in daily energy input (Prowse 1990). The peak $Q_{E}$ roughly corresponds to the peak in $Q^{\circ}$. Although on clear nights $Q^{*}$ was often near $-100 \mathrm{~W} \mathrm{~m}^{-2}$, the release of large amounts of energy from the lake $\left(-Q_{W}\right)$ fueled evaporation and warmed the overlying atmosphere $\left(+Q_{H}\right)$. This process allows $Q_{E}$ to be a substantial component of the energy balance at night. The energy flux across the lake bottom $\left(Q_{\mathrm{G}}\right)$ was ignored because it must be very small given the slight diurnal change in temperature of the sediment. In Table 2 the term $Q_{G}$ represents $Q_{W}$ for Golf Lake.

The seasonal pattern of evaporation from Golf Lake was assumed representative of, and applied to, all open water surfaces in the Eastern Creek drainage basin. The high temperatures and clear conditions in June and August were responsible for very high evaporation rates. The cool wet period in mid-July resulted in subdued evaporation for a period of approximately a week.

\section{Energy balance of land surfaces}

The seasonal energy balances of the 4 land terrain types are summarized in Table $2 . Q^{*}$ is similar for all terrain types except the lichen-heath, which has a noticeably lower value because of a much higher albedo $\{0.24\}$ and warmer surface temperatures (larger longwave radiative loss).

Of the land surfaces, the sedge wetland had the greatest $Q_{E}$, followed by the willow wetland and open forest which had approximately the same $Q_{E}$. The lichen-heath had significantly less evaporation because of less available energy, a lack of transpiring plants, and less moisture available near the surface of the well-drained soils. The role of lichen mats giving rise to a large canopy resistance to the evaporative flux from the soil is recognized, but could not be quantified in this study.

On the drier lichen-heath surfaces, the subdued latent heat flux allows more energy to be used for sensible heating of the air compared to the other surfaces. There was less sensible heating in the open forest, and the least over the willow and sedge wetlands since more energy was dedicated to evaporating water from these wet surfaces.

The smallest ground heat flux occurred in the sedge wetland and in the open forest, with a daily average of approximately $14 \mathrm{~W} \mathrm{~m}^{-2}$. There was more ground heating at the Willow site and the greatest at the Ridge site. The lichen-heath cover at the instrumented Ridge site was thin and patchy compared to sites in the basin where frost-probing was conducted. This coupled with the sandy soils at the Ridge site explains the high $Q_{C}$ values encountered there. Lichen-heath sites within the basin evidently have less ground heating, as indicated by shallow active layers.

The sedge wetland and lichen-heath provide the greatest contrast in terrain energy balances. $71 \%$ of $Q$ ' was used to evaporate water at the sedge site while only $20 \%$ and $9 \%$ of $Q^{\cdot}$ was used for sensible and ground heating, respectively. In contrast, on the upland lichen-heath only $49 \%$ of $Q^{*}$ was used in evaporation while $33 \%$ was used to heat the air and $18 \%$ to warm the soil. While the Bowen ratios of the Sedge, Willow and Forest sites were similar, that for upland lichen-heath was approximately twice as great.

Overall, the most interesting aspect of the energy balance in this study is the uncharacteristically high $Q_{E}$ values. The abnormally hot summer of 1991 is cited as the principal factor responsible for this. Table 3 contains mean daily evaporation values $\left(\mathrm{mm} \mathrm{d}^{-1}\right)$ from the literature for terrain types similar to those in the Eastern Creek drainage basin. Only studies that were conducted during the growing season and in high latitudes appear in Table 3. The results of Lafleur et al. (1992) are directly comparable since the sedge fen and spruce forest sites are the same ones used in this study. The evaporation at these sites in 1991 was 30 to $50 \%$ greater than in the 2 previous years. These high evaporation rates, as will be seen in the following section, have major impacts on the water balance of the drainage basin.

\section{Water balance}

A water balance was computed for the interval of June 21 to August 18, inclusive (Fig. 7). Over the $59 \mathrm{~d}$, $181 \mathrm{~mm}$ of precipitation fell in the Eastern Creek drainage basin. The areally weighted basin evaporation totaled $205 \mathrm{~mm}$. The change in basin storage $(\Delta S)$ was determined using 2 methods. The first, called measured $\Delta S$, used measurements of changes in surface water depths and subsurface water storage in Eq. (4). The second, called calculated $\Delta S$, was determined as a residual from the water balance (Eq. 2). The runoff term had to be corrected for periods when heavy rains caused Stygge Lake to overflow its banks at Willow Creek, which leads to an overestimation of runoff. Identification of periods when bank overflow occurred at Willow Creek and the methods used to correct for this are provided by Boudreau (1993). The runoff had to be adjusted between June 21 and 27 and between July 23 and August 14 (Fig. 6).

The water balance components (in $\mathrm{mm} \mathrm{d}^{-1}$ ) for the whole basin as well as the individual terrain types are given in Table 4. Neglecting water storage, all 
Table 3. Evapotranspiration rates $(E T)$ for terrain types similar to those found in the Eastern Creek drainage basin. Evapotranspiration rates in this study have been converted to $\mathrm{mm}^{-1}$ for comparative purposes

\begin{tabular}{|c|c|c|c|c|}
\hline Location & Period & Terrain type & $\begin{array}{c}E T \\
\left(\mathrm{~mm} \mathrm{~d}^{-1}\right)\end{array}$ & Source \\
\hline $\begin{array}{l}\text { Newfoundland } \\
\left(46^{\circ} 38^{\circ} \mathrm{N}, 53^{\circ} 06^{\prime} \mathrm{W}\right)\end{array}$ & May 26 - Jul 11, 1989 & Blanket bog & 1.7 & Price (1991) \\
\hline $\begin{array}{l}\text { Northern N.W.T } \\
\left(64^{\circ} 27^{\prime} \mathrm{N}, 97^{\circ} 47^{\prime} \mathrm{W}\right)\end{array}$ & Jun 22 - Aug 1, 1983 & Flat fen & 4.5 & Roulet \& Woo (1986b) \\
\hline $\begin{array}{l}\text { Northern Manitoba } \\
\left(58^{\circ} 44^{\prime} \mathrm{N}, 93^{\circ} 49^{\circ} \mathrm{W}\right)\end{array}$ & Jun $16-$ Aug 16, 1985 & Tundra lake & 6.1 & Bello \& Smith (1990) \\
\hline $\begin{array}{l}\text { Northern Manitoba } \\
\left(58^{\circ} 38^{\prime} N, 93^{\circ} 50^{\prime} \mathrm{W}\right)\end{array}$ & Jun $17-\operatorname{Sep} 2,1989$ & $\begin{array}{l}\text { Open spruce, } \\
\text { tamarack }\end{array}$ & 2.1 & Lafleur (1992) \\
\hline $\begin{array}{l}\text { Northern Ontario } \\
\left(51^{\circ} 10^{\prime} \mathrm{N}, 79^{\circ} 47^{\prime} \mathrm{W}\right)\end{array}$ & May 4 - Aug 22, 1984 & $\begin{array}{l}\text { Marsh } \\
\text { Mostly ridges }\end{array}$ & $\begin{array}{l}2.8 \\
2.3\end{array}$ & Price \& Woo (1988) \\
\hline $\begin{array}{l}\text { Labrador } \\
\left(53^{\circ} 33^{\prime} \mathrm{N}, 59^{\circ} 30^{\prime} \mathrm{W}\right)\end{array}$ & Jun 26 - Jul 26, 1989 & String bog & 2.5 & Price et al. (1991) \\
\hline $\begin{array}{l}\text { Northern Ontario } \\
\left(51^{\circ} 08^{\prime} \mathrm{N}, 79^{\circ} 48^{\prime} \mathrm{W}\right)\end{array}$ & May 15 - Aug 16, 1985 & $\begin{array}{l}\text { Alder and willow- } \\
\text { covered ridge }\end{array}$ & 3.0 & Woo \& diCenzo (1989) \\
\hline $\begin{array}{l}\text { Northern Manitoba } \\
\left(58^{\circ} 38^{\prime} \mathrm{N}, 93^{\circ} 50^{\circ} \mathrm{W}\right)\end{array}$ & $\begin{array}{l}\text { Jun } 28 \text { - Aug 30, } 1989 \\
\text { Jun } 19 \text { - Aug 22, } 1990\end{array}$ & $\begin{array}{l}\text { Sedge fen } \\
\text { Spruce forest } \\
\text { Sedge fen } \\
\text { Spruce forest }\end{array}$ & $\begin{array}{l}2.5 \\
2.2 \\
2.7 \\
2.3\end{array}$ & Lafleur et al. (1992) \\
\hline $\begin{array}{l}\text { Northern Quebec } \\
\left(54^{\circ} 52^{\prime} \mathrm{N}, 67^{\circ} 03^{\prime} \mathrm{W}\right)\end{array}$ & May-Sep, 1977 & $\begin{array}{l}\text { Lichen-heath } \\
\text { Willow-birch } \\
\text { Open water }\end{array}$ & $\begin{array}{l}1.7 \\
2.7 \\
2.8\end{array}$ & Wright (1981) \\
\hline $\begin{array}{l}\text { Northern Manitoba } \\
\left(58^{\circ} 45^{\prime} \mathrm{N}, 93^{\circ} 57^{\prime} \mathrm{W}\right)\end{array}$ & Jun 21 - Aug 18, 1991 & $\begin{array}{l}\text { Sedge fen } \\
\text { Lichen-heath } \\
\text { Tundra lakes } \\
\text { Willow-birch } \\
\text { Spruce forest }\end{array}$ & $\begin{array}{l}3.5 \\
2.3 \\
4.8 \\
3.2 \\
3.3\end{array}$ & This study \\
\hline
\end{tabular}

the terrain types except upland lichen-heath had a negative water balance $(P-E T)$. The water balance of open water was highly negative due to the high evaporation rates. Precipitation exceeded evapotranspiration over the study season on the upland lichen-heath. For the basin as a whole $P-E T$ amounted to $-24 \mathrm{~mm}$. Given that there was approximately $145 \mathrm{~mm}$ of runoff over the study period (adjusted $R O$ ), it is obvious that there was a substantial change in storage. To account for the large runoff, approximately $169 \mathrm{~mm}$ would have to have been released from the groundwater and open water reservoirs (calculated $\Delta S$ ).

Over the water balance period the measured $\Delta S$ as indicated by well records was calculated to be negative, but not of a magnitude required to produce the observed runoff. An error analysis of $\Delta S$ (see following section) gave a maximum probable error of $\pm 88 \mathrm{~mm}$. It is apparent that the relative error assigned to the discharge of Willow Creek was greater than $\pm 25 \%$. The mea- sured $\Delta S$ was only $-0.64 \mathrm{~mm} \mathrm{~d}^{-1}$ compared to the calculated $\Delta S$ of $-2.86 \mathrm{~mm} \mathrm{~d}^{-1}$ (Table 4). The determinations do not agree for the following reasons. The calculated $\Delta S$ is likely overestimated and the measured $\triangle S$ is

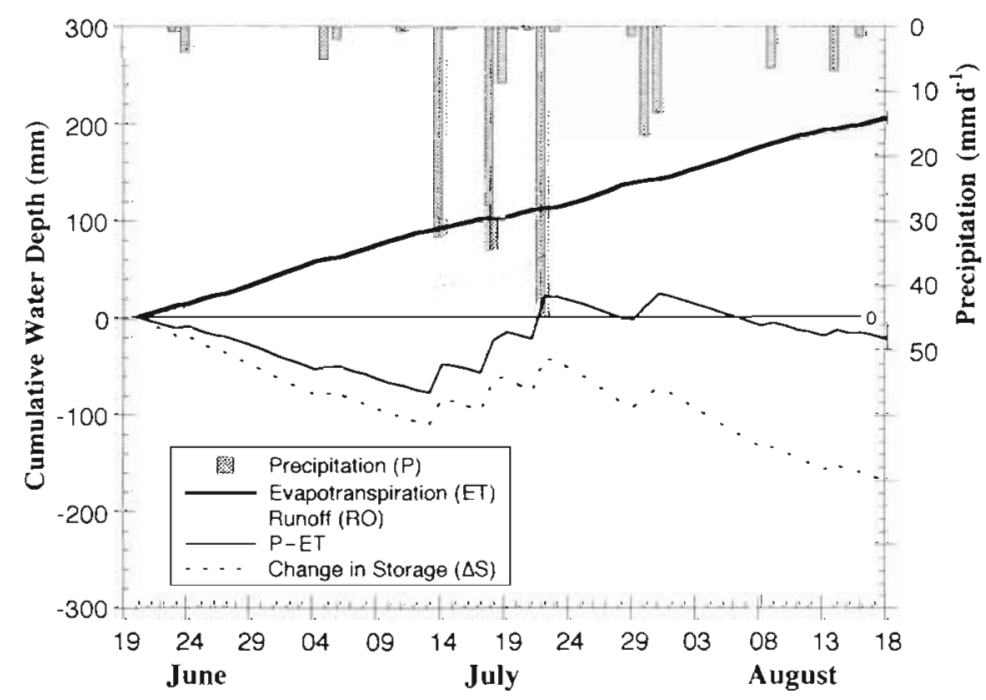

Fig. 7. Cumulative water balance components for the Eastern Creek basin 
Table 4. Water balance for the $59 \mathrm{~d}$ study period (June 21 to August 18). Precipitation (P), runoff (RO), evapotranspiration (ET) and the change in storage $(\Delta S)$ are given in $\mathrm{mm} \mathrm{d}^{-1}$

\begin{tabular}{|c|c|c|c|c|c|c|c|}
\hline \multirow[t]{2}{*}{ Terrain type } & \multirow[t]{2}{*}{$P$} & \multirow{2}{*}{ RO } & \multirow{2}{*}{$E T$} & \multirow[t]{2}{*}{$P-E T$} & \multirow[t]{2}{*}{ Calculated $\Delta S$} & \multicolumn{2}{|c|}{ Measured $\Delta S$} \\
\hline & & & & & & Mean & SD \\
\hline Whole basin & 3.07 & 2.46 & 3.47 & -0.40 & -2.86 & -0.64 & 0.40 \\
\hline Sedge wetland & 3.07 & & 3.54 & -0.47 & -2.93 & -0.39 & 0.37 \\
\hline Upland lichen-heath & 3.07 & & 2.33 & 0.74 & $-1.72^{d}$ & -0.41 & 0.32 \\
\hline Lakes and ponds & 3.07 & & 4.79 & -1.72 & $-4.18^{\mathrm{a}}$ & $-1,56$ & 0.68 \\
\hline Willow wetland & 3.07 & & 3.23 & -0.16 & $-2.62^{d}$ & -0.49 & 0.35 \\
\hline Open spruce forest & 3.07 & & 3.26 & -0.19 & $-2.65^{\mathrm{d}}$ & -1.28 & 0.26 \\
\hline
\end{tabular}

underestimated. Underestimation of the measured basin $\Delta S$ during dry periods was likely due to the difficulties of obtaining accurate and representative measurements of $\triangle W L$ and $Y_{\mathrm{s}}$ in the open forest and on lichen-heath. Collectively, these 2 terrain types occupy $22 \%$ of the basin. The measured $\Delta S$ values for open water, willow and sedge sites are also believed to be underestimations. Due to logistic and equipment constraints, a dense network of groundwater wells could not be installed in the basin, particularly through the middle of the basin where dense willow thickets impede access. In this region of the basin, extensive areas of inundated willows and swamps at the beginning of the measurement period had ponded water over $0.5 \mathrm{~m}$ deep in many locations. By the end of the summer the water table in most of these areas had dropped near or slightly below the surface. This phenomenon also points out the fact that the areal extent of open water can significantly expand and contract over the course of the growing season; altering the spatial representation of the terrain types. Turning now to the calculated $\Delta S$, these values are likely overestimated given the conservative correction for periodic bank overflow at Willow Creek (causing an overestimation of $R O$ and thus $\Delta S$ ). Differences between the measured and calculated $\Delta S$ for each terrain type stem from the fact that the calculated $\Delta S$ was determined solely by changes in $E T$, since $P$ and $R O$ were prorated for the individual terrain types. Although it is reasonable to expect $P$ to be very similar over all terrain units, the uplands will have different runoff rates from the lowlands. This is particularly important in the open forest where residual snow banks persisted until June 18, augmenting runoff even after their disappearance.

\section{Error analysis}

The potential for measurement error enters into all aspects of the energy budget and water balance. In addition to measurement error, the use of simplifying assumptions, parameterizations, and the methods of calculation will determine the propagation of errors. The method of 'scaling up' the evaporation from the various terrain types for an estimate of regional ET will be complicated by the advection of energy, especially across the smaller terrain units. In the water balance, an occasional source of error may be the assumption that groundwater flow and surface runoff across the basin boundary (other than through the monitored creeks) were assumed negligible.

The results of formal analyses of errors in the energy and water balance have been extensively documented. Detailed analyses of error in the BREB approach have been provided by Fuchs \& Tanner (1970), Winter (1981) and Papakyriakou \& McCaughey (1991). Measurement accuracy and resolution for the equipment used in this project are given by Boudreau (1993). A detailed analysis of error in the BREB method using data collected by equipment and methods similar to those used in this study can be found in Lafleur (1988). He assigned an error of $\pm 7 \%$ to the measurement of $Q^{*}, \pm 20 \%$ to the calculation of $Q_{G}, \pm 1 \%$ for the calculation of vapour pressure, and $\pm 8 \%$ as the average relative error in the Bowen ratio $(\beta)$ for the $75 \%$ percentile. Based on the tables provided by Lafleur (1988) and using $\beta$ values representative of each terrain type in this study, the maximum relative error in $Q_{E}$ was approximately $\pm 20 \%$ for the wetlands (sedge, willow and open water) and $\pm 25 \%$ for open spruce forest and upland lichen-heath. The prorated error in the basinaveraged $E T$ was approximately $\pm 21 \%$.

Details of the calculation of relative and probable errors (following Bevington 1969, p. 113) in this water balance are given by Boudreau (1993) and the results are summarized in Table 5. Based on the maximum probable errors associated with ET, $P$ and $R O$, the result of an analysis of the linear combination of errors associated with the calculation of $\Delta S$ as a residual from the water balance gave a maximum probable error of $\pm 88 \mathrm{~mm}$. 
Table 5. Errors associated with the water balance components (evapotranspiration, ET; precipitation, $P_{;}$runoff, $R O_{i}$ discharge of Lower Eastern Creek, $D_{\text {LEC }}$ of Upper Eastern Creek, $D_{\text {UEC }}$ and of Willow Creek, $\left.D_{\text {Willow }}\right)$. Measured data correspond to an interval between June 21 and August 18, 1991

\begin{tabular}{|c|c|c|c|c|c|}
\hline Variable & Measured & Relative error & Max. relative error & Probable error & $\begin{array}{c}\text { Max. probable } \\
\text { error }\end{array}$ \\
\hline Basin ET & $205 \mathrm{~mm}$ & $20 \%$ & $25 \%$ & $41.0 \mathrm{~mm}$ & $51.3 \mathrm{~mm}$ \\
\hline Basin $P$ & $181 \mathrm{~mm}$ & $5 \%$ & $10 \%$ & $9.1 \mathrm{~mm}$ & $18.1 \mathrm{~mm}$ \\
\hline$D_{\text {LEC }}$ & $9.188 \times 10^{6} \mathrm{~m}^{3}$ & $5 \%$ & $5 \%$ & $459400 \mathrm{~m}^{3}$ & $459400 \mathrm{~m}^{3}$ \\
\hline$D_{\text {UEC }}$ & $4.512 \times 10^{6} \mathrm{~m}^{3}$ & $5 \%$ & $5 \%$ & $225600 \mathrm{mi}^{3}$ & $225600 \mathrm{~m}^{3}$ \\
\hline$D_{\text {willow }}$ & $2.243 \times 10^{6} \mathrm{~m}^{3}$ & $5 \%$ & $25 \%$ & $112150 \mathrm{~m}^{3}$ & $560750 \mathrm{~m}^{3}$ \\
\hline Basin area & $1.154 \times 10^{7} \mathrm{~m}^{2}$ & $1 \%$ & $10 \%$ & $115400 \mathrm{~m}^{2}$ & $1154000 \mathrm{~m}^{2}$ \\
\hline Basin $R O$ & $211 \mathrm{~mm}$ & $22 \%$ & $33 \%$ & $45.5 \mathrm{~mm}$ & $69.1 \mathrm{~mm}$ \\
\hline
\end{tabular}

\section{SUMMARY AND CONCLUSIONS}

The main objectives of this study were to establish an experimental drainage basin, measure and integrate the energy balance of individual terrain types, and calculate the water balance of the basin. This is the first study that has analyzed summertime Subarctic basin hydrology in terms of measured evapotranspiration and energy and water balance components for individual terrain types. The 5 terrain types identified in the experimental basin represent the majority of those found in the coastal zone of the Hudson Bay Lowland.

The topography, soils, and vegetation cover of these terrain units all play pivotal roles in determining their energy and water balances. Measurements show the energy balance to be significantly different between upland and lowland terrain types. This creates large differences in their individual water balances. Changes in the areal extent of the terrain types within the basin would significantly alter the water balance due to the variable evaporation rates. Although it may take decades for a change in climate to significantly alter the vegetation composition of large areas, impacts of a change in climate would immediately affect evaporation. This study suggests that increased radiation (decreased cloud cover) and temperature $\left(3^{\circ} \mathrm{C}\right.$ above normal) can increase evapotranspiration from certain terrain types by 30 to $50 \%$ over climatically 'normal' summers. It is important to note that other factors also exert strong controls on evapotranspiration (e.g. moisture availability) and therefore predictions and models should not be restricted to the variables of radiation and temperature alone.

This study has shown that a wetland underlain by permafrost can sustain streamflow even during periods of drought. It has also shown that both the drier upland portions and the wetlands play an important role in sustaining runoff. Results indicate that the terrain composition of a basin is very important to its water balance and watershed yield. Although the contribution of each terrain type to the runoff generated from the whole basin could not be quantified, indicators such as soil moisture and water table fluctuation allow a qualitative assessment. The ridges that are vegetated by lichen-heath or spruce forest are believed to shed a large proportion of their stored water to the surrounding wetlands. When the water table is at or near the surface, a well-integrated drainage network can quickly convey water to the streams.

The Eastern Creek basin accounted for approximately $20 \%$ of the total runoff from the whole watershed drained by Eastern Creek. The extensive drainage network in the Eastern Creek basin that taps many lakes allows streamflow to have a large and rapid response to major rain events. The water balance of the basin indicates that withdrawal of stored water sustains both evaporation and streamflow. Thus even during hot and dry periods when evapotranspiration is very large, there is still a substantial yield to streamflow.

Since peatlands occupy over half of the basin, their role in regulating streamflow is important. Antecedent moisture conditions in the upper peat layers determine the magnitude and timing of streamflow response to runoff. After prolonged drought, streamflow response to large rainfalls is subdued with a longer lag time. After sustained rainfalls, the storage capacity of the peat may be exceeded, resulting in overland flow and a very fast and large response by the stream to subsequent rainfalls. Once the water table falls below the surface, streamflow quickly tapers off. Slow release of water from the groundwater reservoir and thawing soil sustain streamflow during dry conditions.

The change in groundwater storage was the most difficult term of the water balance to quantify. The calculation of the change in storage for individual terrain 
types as a residual from the water balance by using the basin runoff rate is not valid for the Eastern Creek basin. It is apparent that individual terrain types have very different groundwater hydrologies, and radiation and energy balances. The ridges lose their groundwater most rapidly in discharge to the adjacent wetlands. Because of this, the ridges had the greatest range of water table depths and the lowest soil moisture. In contrast, the water table fluctuated the least in the sedge wetlands, which displayed the highest soil moisture storage with only a small seasonal range and great spatial uniformity.

This research illustrates the unique nature of shallow tundra lakes and ponds. Their ability to store heat promotes nighttime evaporation, and daytime evaporation is enhanced by high net radiation and advection of warm dry air from the surroundings - especially during a hot summer. The open water surfaces typically had the greatest evaporation due to the advected heat input. In this study advection effects may have been intensified due to the unusually hot summer. Although open water surfaces amounted to roughly $17 \%$ of the basin, the high evaporation rates gave lakes and ponds an impact on the water balance much greater than their areal coverage suggests.

Because of the sunny and warm conditions, evaporation from land surfaces was relatively high compared to other studies and previous years of measurements at some of the same sites. During the growing season net radiation was high over all terrain units, with lakes having the highest followed by the wetlands, while lichen-heath communities had the least. The evaporative heat flux as a proportion of net radiation was smallest over lichen-heath, greater in willow and forested areas and greatest for the lake. Evaporation from the lake was twice that from the lichen-heath.

In the spring, the frost table acts as a highly impermeable boundary which is responsible for rapid runoff and fast response of streamflow to rain events when it is near the surface. Soil moisture and vegetative cover are the primary factors in active layer development. In the willow and sedge wetlands where the soil was normally wet (high thermal conductivity and low albedo), a deep active layer developed. In contrast, the dry upland areas, and in particular lichen-heath, had only shallow active layers. The frost table was closest to the surface in areas which had thick mats of lichen and heath, which provide the underlying soil with thermal insulation.

This study has provided valuable energy and water balance data for one of Canada's least studied and understood ecosystems. The dominant terrain types identified in these coastal Subarctic wetlands were found to have large differences between their energy and water balance components. The calculation of basin-scale evapotranspiration from only one terrain type would be inappropriate and could lead to a large error in the water balance. The linear scaling-up approach used in this study is believed to give a realistic impression of the overall evapotranspiration. Using the high temperatures and net radiation experienced in 1991 as an analog for a climate warming scenario, results suggest that summer warming would cause a substantial increase in evaporation and a large negative change in groundwater storage in Subarctic wetlands.

Acknowledgements. The authors thank John Volek for his assistance in the field. Drs Richard L. Bello and John J. Drake generously loaned equipment to make this project feasible Dr Peter M. Lafleur and Blair Mantha operated the Forest site and provided the energy balance data. Similar data were also supplied by Peter Blanken for the Willow site and David Wessel for the Sedge site. Derek Carlson provided invaluable field assistance in addition to the setup and data reduction of the Ridge site. Cliff Brettle designed and built required instruments and equipment. Financial assistance for this research was provided by the National Science and Engineering Research Council of Canada (W.R.R.) and a northern student training grant from the Department of Indian and Northern Affairs (L.D.B.). Logistical support was provided by the Churchill Northern Studies Centre.

\section{LITERATURE CITED}

Bello RL, Arama A (1989) The water balance of lichen canopies. Climatol Bull 23:74-78

Bello RL, Smith JD (1990) The effect of weather variability on the energy balance of a lake in the Hudson Bay Lowlands, Canada. Arct alp Res 22:98-107

Bevington PR (1969) Data reduction and error analysis for the physical sciences. McGraw-Hill, New York

Blanken PD, Rouse WR (1994) The role of willow-birch forest in the surface energy balance at treeline. Arct alp Res 26:403-411

Boelter DH (1975) Methods for analyzing the hydrological characteristics of organic soils in marsh-ridden areas. In International Symposium on the Hydrology of MarshRidden Areas. Proceedings of the Minsk Symposium, June 1972. UNESCO Press, IAHS, Paris, p 161-169

Boudreau LD (1993) The energy and water balance of a high subarctic wetland underlain by permafrost. MSc thesis, McMaster University, Hamilton, Ontario

Danielson EW (1969) The surface heat budget of Hudson Bay. Marine Science Manuscript, Rep No 9, McGill University, Montreal

Dooge $J$ (1975) The water balance of bogs and fens. In: International Symposium on the Hydrology of Marsh-Ridden Areas. Proceedings of the Minsk Symposium, June 1972. UNESCO Press, IAHS, Paris, p 233-271

Eggelsmann R (1975) The water balance of lowland areas in northwestern regions of the FRG. In: International Symposium on the Hydrology of Marsh-Ridden Areas. Proceedings of the Minsk Symposium, June 1972. UNESCO Press, IAHS, Paris, p 355-367

EWG (1989) Ecoclimatic regions of Canada, first approximation. Ecoregions Working Group of the Canada Committee on Ecological Land Classification. Ecological Land Classifi- 
cation Series, No 23, Sustainable Development Branch, Canadian Wildlife Service, Environment Canada, Ottawa

Fuchs M, Tanner CB (1970) Error analysis of Bowen ratios measured by differential psychrometry. Agric Meteorol 7: $329-334$

Halliwell DH, Rouse WR (1987) Soil heat flux in permafrost: characteristics and accuracy of measurement. J Climatol $7: 571-584$

Halliwell DH, Rouse WR (1989) A comparison of sensible and latent heat flux calculations using the Bowen ratio and aerodynamic methods. J atmos ocean Technol 6:563-574

Lafleur PM (1988) Surface cover and air mass controls on evaporation from a subarctic marsh. PhD thesis, McMaster University, Hamilton, Ontario

Lafleur PM (1992) Energy balance and evapotranspiration from a subarctic forest. Agric For Meteorol 58:163-175

Lafleur PM, Rouse WR, Carlson DW (1992) Energy balance differences and hydrologic impacts across the northern treeline. Int J Climatol 12:193-203

Markham WE (1986) The ice cover. In: Martini IP (ed) Canadian inland seas. Elsevier Oceanography Series 44. Elsevier Science Publishing Co, Inc, New York, p 101-116

Moore TR (1986) Carbon dioxide evolution from subarctic peatlands in eastern Canada. Arct alp Res 18:189-193

Moore TR, Knowles R (1989) The influence of water table levels on methane and carbon dioxide emissions from peatland soils. Can J Soil Sci 69:33-38

NWWG (1987) The Canadian wetland classification system. National Wetlands Working Group of the Canada Committee on Ecological Land Classification. Ecological Land Classification Series, No 21, Lands Conservation Branch, Canadian Wildlife Service, Environment Canada, Ottawa

Oechel WC. Hastings GV, Vourlitis G, Jenkins GR, Riechers G, Grulke N (1993) Recent change of Arctic tundra ecosystems from a net carbon dioxide sink to a source. Nature $361: 520-523$

Papakyriakou TN, McCaughey JH (1991) An evaluation of the water balance technique for the estimation of evapotranspiration for a mixed forest. Can J For Res 21. $1622-1631$

Pasquill F (1972) Some aspects of boundary layer description. Q J R Meteorol Soc $98: 469-494$

Phillips D (1990) The climates of Canada. Environment Canada Canadian Government Publishing Centre, Supply and Services Canada, Ottawa

Price JS (1991) Evaporation from a blanket bog in a foggy coastal environment. Boundary-Layer Meteorol 57: 391-406

Price JS, Maloney DA, Downey FG (1991) Peatlands of the Lake Melville Coastal Plain, Labrador. In: Prowse TD, Ommanney CSL (eds) Northern hydrology: selected perspectives. Proceedings of the Northern Hydrology Symposium, No 6. Environment Canada. Canadian Government Publishing Centre, Supply and Services Canada, Ottawa, p 293-302
Price JS, Woo MK (1988) Studies of a subarctic coastal marsh 1. Hydrology. J Hydrol 103:275-292

Price $M$ (1985) Introducing groundwater. George Allen \& Unwin, Inc, Winchester, MA

Priestley CHB, Taylor RJ (1972) On the assessment of surface heat flux and evaporation using large scale parameters. Mon Weather Rev 100:81-92

Prowse TD (1990) Northern hydrology: an overview. In: Prowse TD, Ommanney CSL (eds) Northern hydrology: Canadian perspectives. Environment Canada, NHRI Science Rep No 1. Canadian Government Publishing Centre, Supply and Services Canada, Ottawa, p 1-36

Rizzo B, Wiken E (1992) Assessing the sensitivity of Canada's ecosystems to climate change. Clim Change 21:37-55

Roots EF (1989) Climate change: high-latitude regions. Clim Change 15:223-253

Roulet NT, Woo MK (1986a) Wetland and lake evaporation in the low Arctic. Arct alp Res 18:195-200

Roulet NT, Woo MK (1986b) Hydrology of a wetland in the continuous permafrost region. J Hydrol 89:73-91

Rouse WR (1984a) Microclimate at Arctic treeline: I. Radiation balance of tundra and forest. Water Resour Res 20:57-66

Rouse WR (1984b) Microclimate at Arctic treeline: II. Soil microclimate of tundra and forest. Water Resour Res 20: $67-73$

Rouse WR (1991) Impacts of Hudson Bay on the terrestrial climate of the Hudson Bay Lowlands. Arct alp Res 23: $24-30$

Rouse WR, Carlson DW, Weick EJ (1992) Impacts of summer warming on the energy and water balance of wetland tundra. Clim Change 22:305-326

Scott PA, Bentley CV, Fayle DCF, Hansell RIC (1987) Crown forms and shoot elongation of white spruce at the treeline, Churchill, Manitoba, Canada. Arct alp Res 19:175-186

Weick EJ, Rouse WR (1991) Advection in the coastal Hudson Bay Lowlands: I. The terrestrial surface energy balance. Arct alp Res 23:328-337

Wessel DA, Rouse WR (1994) Modelling evaporation from wetland tundra. Boundary-Layer Meteorol 68:109-130

Winter TC (1981) Uncertainties in estimating the water balance of lakes. Water Res Bull 17:82-1.15

Woo MK, diCenzo PD (1989) Hydrology of small tributary streams in a subarctic wetland. Can J Earth Sci 26: $1557-1566$

Wright RK (1981) The water balance of a lichen tundra underlain by permafrost. McGill Subarctic Research Paper No 33, Centre for Northern Studies and Research, McGill University, Montreal

Wright RK (1982) Modelling the thaw-season runoff in Nouveau-Québec. Naturaliste Can 109:469-479

Zoltai SC, Pollett FC (1983) Wetlands in Canada: their classification, distribution, and use. In: Gore AJP (ed) Ecosystems of the world, Vol 4B, Mires: swamp, bog, fen and moor - regional studies. Elsevier Scientific Publishing Company, New York, p 245-268 